\title{
TRANSNATIONALISM AS AN INDEX TO CONSTRUCT EUROPEAN IDENTITIES: AN ANALYSIS OF 'TRANSEUROPEAN' DISCOURSES
}

\author{
Franco Zappettini \\ University of Genoa \\ 5 Via Balbi, 16126 Genoa, Italy
}

\begin{abstract}
Transnationalism is a multifaceted phenomenon which has impacted on society and challenged, inter alia, the paradigm of national affiliations. The trasnationalisation of the EU-ropean field has arguably contributed to a political arena where embryonic post-national identities and new forms of belonging are being negotiated, challenged and legitimized. By investigating the discourses of members of a transnational NGO of 'active' citizens, this paper seeks to understand how current European identities are discursively constructed from bottom up in the public sphere. Appropriating CDA this paper offers insights into how discursive strategies and linguistic devices used by the speakers, and predicated on the indexicality of transnational frames, construct Europe and patterns of belonging to it. This paper suggests different conceptual dimensions of transnationalism enacted by members in discourse which are conveniently summarised as: nation-centric, Euro-centric, and cosmopolitan.
\end{abstract} lic sphere

Keywords: Transnationalism, discursive strategies, post-national identities, linguistic devices, pub-

\section{INTRODUCTION}

In the last two decades the growing complexity, diversification and context-dependency of European identities has been the focus of much academic interest in a number of disciplines including politics, sociology, psychology, philosophy, linguistics, critical and cultural studies (cf. for example Oberhuber 2007, Balibar 2004, Fligstein 2008, Delanty and Rumford 2005, Checkel and Katzenstein 2009, Cerutti and Lucarelli 2008, Friedman and Thiel 2012, Eder 2009, Herrmann et al. 2004, Mole 2007, Stråth 2010, Krzyżanowski 2010, Wodak 2004, Wodak and Weiss 2005, DeBardeleben 2011, Morin and Carta 2014). Although such body of literature has provided significant insights on the many fluid transformations of Europe(anness), very few studies have illuminated how European identities are being negotiated and transformed among social actors visà-vis global changes and increasingly transnationalised societies which "make obsolete conventional understandings of identity formation and its processes" (Haller 2005: 1183).

The general aim of this paper is thus to contribute to an interdisciplinary and transnational approach to the gamut of European identities emerging and transforming in 'late modernity'. By focusing on the discourses of a transnational association of 'active' citizens, this paper strives to illuminate a specific locus of negotiation of Europeanness 
where social imaginaries of Europe interplay with wider transnational discourses. Furthermore, this paper aims to provide qualitative insights on the construction of Europeanness from a bottom-up/grassroots perspective subscribing to Kraus' view (2006: 205) that "a common European identity cannot simply be created 'from above" and taking up Krzyżanowski's (2010) call for research to "turn to social action as the main force driving the dynamics of contemporary identities" (p. 201).

The paper is structured as follows. Firstly, it argues the case for exploring (European) identities from a transnational perspective in the wake of processes of 'late modernity'. It then provides some background on the organisation investigated and the methodology used. Secondly, it outlines a theoretical framework for the examination of European discourses that takes into account indexicality as an 'entry point' for the interpretation of different 'social imaginaries' of Europe and/in the world. Thirdly, the paper engages with a Critical Discourse Analysis of the data focusing on the illustrations of some linguistic realisations and suggesting their indexical valence in the construction of members' Europeanness. It then introduces a taxonomy of European imaginaries constructed by members around different 'deictic centres'. This article will finally conclude with some considerations on the relevance and limitations of findings.

\section{A TRANSNATIONAL ${ }^{1}$ APPROACH TO IDENTITIES}

Identity has been a major topic of investigation and debate in social sciences especially in the last few decades. Whilst social psychology has substantially conceptualised identity as a salient link between the individual and a social groups (Tajfel and Turner 1979, Jenkins 2004) or an 'imagined community' (Anderson 2006), social constructivism has underscored how identities should be accounted for as dynamic, multiple and fluid constructs that emerge, inter alia, from discursive negotiation rather than existing in reified forms (see for example Hall 1996a, Hall 1996b, Hall 1997). For most critical linguists, therefore, discourses of identity must be seen dialogically related with and mutually constitutive of social structures and their transformation (Fairclough and Wodak 1997). Whilst nation-states have represented a major source of identification in the last three centuries (Hobsbawm 1997) and, in some cases, they can still provide powerful identity anchoring (Wodak 2012), national affiliations should no longer be taken for granted as stable identitarian parameters in 'late modernity'. Beck et al. (1994) define late modernity as a socio-historical context characterized, inter alia, by processes of globalization, the expansion of networks, the decline of grand narratives and the emergence of postnational powers - including the EU - that have profoundly impacted on how individuals conceive the organization of social orders and political communities (cf. also Held 1999, Lyotard and Benjamin 1989, Habermas 2001, Castells 1997). In this vein

1 Transnationalism is a multi-faceted phenomenon that comprises, inter alia, of cultural, political, and economic dimensions (Vertovec, 2009). In this paper I use the term transnationalism to conveniently refer to 'multiple ties and interactions linking people across the borders of nation-states' Vertovec (1999 p. 447) which have impacted on several dynamics of 'nationhood'. I acknowledge that terms such as transnationalism, post-nationalism ad cosmopolitanism are not necessarily synonyms (see Roudometof (2005) for a distinction). 
Beck (1996) has drawn attention to the emergence of a global or cosmopolitan reflexivity in modern polities contending that there is "a new dialectic of global and local questions which do not fit into national politics" (p. 29) and which can only be "properly posed, debated and resolved" (ibid) in a transnational framework which increasingly involves non-state actors.

In many cases the de-territorialisation of cultural practices has allowed for new forms/opportunities of membership, social solidarity and civic participation to emerge across unbounded 'habitats of meaning' (Hannerz 1996) which must take into account influences and variables brought about by multiple cultural and social contexts of 'translocality' and 'glocal' practices (Appadurai 1995). For example much literature has noted how transnational social fields ${ }^{2}$ have redefined traditional referents of groupness (such as citizenship, ethnicity, language), established political actors (such as national institutions) and their roles in the imagination of civic and cultural communities and their solidarity ties (see for example Bauböck and Faist 2010, Sassen 1996, Kastoryano 2003, Albert 2001, Kastoryano 2002, Blommaert 2013).

Hence, in investigating (European) identities in 'late modernity' this paper recognizes the need to move away from 'methodological nationalism' (Wimmer and Schiller Glick 2002) and it aligns itself with a transnational perspective that makes sense of social interaction beyond the 'container theory of society' (Beck 2008). At the same time, transnational dynamics cannot be assumed as a linear process that will eventually lead to the formation of a unified world identity (Shani 2011, Rumford 2008). In fact the complexity of transnationalism lies in the interplay of global and local forces resulting in diversified 'glocal' instantiations of identity (Robertson 1992). To adequately capture the complexity of such dynamics Levitt and Schiller (2004: 1010) argue for the adoption of "a transnational social field approach to the study of social life that distinguishes between the existence of transnational social networks and the consciousness of being embedded in them". Levitt and Glick-Schiller (ibid) suggest that it is possible for individuals in transnational fields to engage in a simultaneity of connections spanning from routines and daily activities, to the production of (cultural) identities that reflect their multiple locations. From this perspective Levitt and Glick-Schiller, define ways of being in social fields as opposed to ways of belonging referring to the former as "the actual social relations and practices that individuals engage in rather than to the identities associated with their actions" and to the latter as "practices that signal or enact an identity which demonstrates a conscious connection to a particular group [...] and an awareness of the kind of identity that action signifies". Whilst for Levitt and GlickSchiller local and transnational connections can occur simultaneously, ways of being and ways of belonging are often dependant on the specific context upon which they are enacted, and therefore they suggest that whilst individuals embedded in a social field have the potential to identify with any label associated with that field, not all choose to do so.

${ }^{2}$ For Levitt and Glick-Schiller (2004) a transnational field typically contains "institutions, organizations, and experiences, within their various levels, that generate categories of identity that are ascribed to or chosen by individuals or groups" (p. 1010). 


\subsection{Europe as a transnational social field and the European Public Sphere}

Europe (inclusive of its geographical, social, political and economic aspects) represents a transnational field of its own where processes of transnationalisation have been significantly compounded by the post-national integration project started by the EU institutions. Such project has manifested itself at many different levels, for example in supranational forms of governance and the free circulation of goods, capital, services, and people within Member States. Moreover, as well as the site of incoming diaspora and exogenous migration patterns, Europe has become to represent a site of 'desirable' internal mobility for many EU citizens ${ }^{3}$. Whilst these practices have not necessarily resulted in a full post-national 'consciousness' at mass level, they have nonetheless contributed to a stratified society where transnational elements have filtered down to citizens differently (Hanquinet and Savage 2013). Moreover, whilst patterns of economic and political convergence have increased, the 'European field' has also amplified the antimonies between the 'global' and the 'local', the 'universal' and the 'particular' dimensions of the EU project (Wodak and Weiss 2005). These tensions are often reflected in multifarious, fragmented, and 'in-between' forms of European identifications which, as most recent 'snapshots' have highlighted, are emerging between agentive, structural, individual, and collective dimensions (Krzyżanowski 2010, McEntee-Atalianis and Zappettini 2014, Checkel and Katzenstein 2009, Biebuyck and Rumford 2011).

Following on Delanty's (2013) suggestion that European identity "is best evidenced in specific sites of communication [such as] debates about Europe" (p. 265), this paper regards the European public sphere (EPS) as one significant locus of investigation for the emergence and negotiation of 'new' transnational European identities. Put succinctly, the public sphere is "a network for communicating information and points of view" (Habermas and Rehg 1998: 360), to discuss and deliberate on public issues which, in modern and deliberative democracies, is seen as a forum for civic participation and the formation of public opinion (Wodak and Koller 2008). Habermas sees the EPS as a transnational site of participation in the democratic debate on European issues which must exist for a European civic identity to emerge and for the European project to be fully legitimized. Although there is little consensus as to whether (and to which extent) the EPS exist in transnational forms (see, inter alia, Closa 2001, Salvatore et al. 2013, Eriksen and Fossum 2001, Splichal 2006, Triandafyllidou et al. 2009, Risse 2010), an increasing number of European social actors — such as non-governmental organizations (NGOs) and (in)formal networks - have emerged in recent years which are focused on transnational clusters of interests (Kaiser 2010, Della Porta and Tarrow 2005). It is to one of such organizations, called Democratic Change for Europe (DC4E) ${ }^{4}$, that this paper now turns to in order to investigate how its members make sense of their Europeanness in relation to transnational practices and their imagination of community.

\footnotetext{
3 However, see (Balibar, 2009) for a critique of 'Fortress Europe'.

${ }^{4}$ A pseudonym is used to protect the anonymity of informants.
} 


\section{FOCUS: BACKGROUND AND DATA}

DC4E, which characterizes itself as a transnational association of citizens, has been campaigning since $2007^{5}$ to influence European policies beyond national remits and it is part of a larger umbrella of organizations of the civil society ${ }^{6}$. The organization has, to date, 19 local offices across Europe and is run on a voluntary basis by ordinary citizens $^{7}$ who share an ideological commitment to the grassroots development of a 'more just and open' social Europe. Transnational meetings are held on a rotational basis and activities are run simultaneously across branches. Typical activities consist of (on and offline) campaigns, cultural events, seminars, debates, and proposals to the EU organs with recent activities including a citizens' manifesto and several proposals under the Citizens' initiative programme ${ }^{8}$. The salience of investigating DC4E lies therefore in the NGO's cross-border set up and, most of all, in its advocacy for framing the debate over European issues within the construction of a transnational (civic) community. Taking indexicality (see section 4.1 below) as an 'entry point' for the investigation of members' belonging to such an 'imagined community', the specific objective of this paper is to identify how European identities are represented, constructed, and negotiated in the member's discourses and how the imagination of European and transnational affiliations interplay. The research questions are articulated as follows:

- Which frames do speakers construct and draw from in representing themselves as Europeans?

- How is transnationalism conceptualized in the discourses of members?

- What is the role of nationhood in members' constructions of Europeanness?

Data was collected via four focus groups and nine individual interviews conducted with DC4E's members in seven locations across Europe between 2010 and 2013 (see Appendix for details). The focus groups were moderated and attended by 17 participants in total. All interviews were conducted in English, except the focus group in Bologna (Italy) and Cluj (Romania) which were conducted in Italian and Romanian respectively and the interview with BE2 which was conducted in Italian'. All participants represent

5 DC4E originated in 2006 from the initiative of a few activists who received some funding under the 'PLAN D for Democracy, Dialogue and Debate'. This scheme was launched by the Commission to address the 'communication gap' between institutions and citizens in the wake of the failed European Constitution in 2004/5. Since then DC4E has been increasingly reliant on private sponsors and membership fees.

${ }^{6}$ see http://euplus.org for further details.

7 The physical location of branches is not necessarily correlated to members' nationality (e.g. Italian, French, Germans, Turkish as well as British nationals are based at the London office).

${ }^{8}$ Introduced under the Treaty of Lisbon the European Citizens' initiative is a legal provision that allows EU citizens to put forward legislation proposals to the European Commission (for details and legal requirements see http://www.citizens-initiative.eu/?page_id=2). Accessed 13/3/2014.

9 All interviews in Romanian and Italian were translated in English. All excerpts presented later in the analysis are in the English version. All focus groups were conducted in situ at the local branch of DC4E. All individual interviews were conducted over Skype, except RO1 who was interviewed at DC4E Rome office and LO3 who was interviewed at a public location in London. 
a self-selecting sample of members who responded to an initial call sent via each branch's gatekeepers. Due to mixed national make-up of each local group ${ }^{10}$ and the transnational approach to the design of this study, certain variables of participants (i.e. their nationality, residency and patterns of mobility) were not controlled. However participants were profiled for these and other socio demographics through a questionnaire distributed at the end of each interview (see Table 1 in Appendix for a summary of results). Group and individual discussions were initiated with open questions derived from the literature review on transnationalism and from familiarization with the organizational literature (e.g. newsletters, website, and Facebook pages). Examples of questions asked include: 'Do you consider yourself European?'; 'What does transnationalism mean to you?'; 'Can you describe Europe from a transnational perspective?'; 'What are your organizational/personal objectives as a member of DC4E?'. Furthermore, in some cases, members voluntarily initiated personal narratives through which they developed 'secondary' topics (Jones and Krzyżanowski, 2008) such as, for example, their own family history, experience abroad, and their engagement in other associations or with other interests.

\section{THEORETICAL APPROACH TO THE ANALYSIS}

The theoretical framework largely draws on Critical Discourse Analysis (CDA) that sees discourse and society as mutually constitutive (Fairclough and Wodak 1997). For CDA, language does more than the mere communication of information, for in and through discourses we also construct social meanings. In CDA discourses therefore describe the world as much as they constitute "situations, objects of knowledge, and the social identities of and relationships between people and groups of people" (Fairclough et al. 1997: 358). From this perspective, the construction of identities can be seen as enacted in and through discursive acts in which social actors articulate one's 'situatedness' (Hall 1997) by representing themselves and others. Trading on the dialogical nature of discourse, CDA sees linguistic resources used by speakers to construct their 'locations' encoding larger ideological stances on 'ways of being' in and 'ways of belonging' in the world. As Davies and Harre' (2001: 262) argue: "[t]he words the speaker chooses inevitably contain images and metaphors which both assume and invoke the ways of being that the participants take themselves to be involved".

In this sense, for example, linguistic realisations of national groupness can be achieved, inter alia, via metaphorical/metonymical inferences to 'family' and 'home', via the personification/agentification of nation as 'motherland/fatherland' and, furthermore, via the inclusiveness/exclusiveness of certain pronouns or possessive adjectives (e.g. we/us/our) (cf. Wodak et al., 2009). At the same time, these ways of talking about nationhood can crystallise in socially shared frames which become available for one to draw upon to discursively reproduce her nationality (Billig 1995).

${ }^{10}$ Local groups across Europe are open to all EU and third-country citizens regardless of their nationality or residency. Geographical locations of branches therefore do not necessarily reflect members' variety. 
With regards to the specific organisation examined in this study, McEntee-Atalianis and Zappettini (2014) have offered insights on members' metaphorical realisations suggesting how speakers often challenged established conceptualisations of nationhood. Instead (McEntee-Atalianis and Zappettini 2014) have suggested that members made sense of their Europeanness and their transnational activities through the metaphorical scenario of spatial dynamics and how such scenario represented a salient referent for members' sense of community, especially in relation to entailments of network and interconnectedness. Building on the insights of this previous study, this paper develops a further line of analysis which interprets the data through the tool of indexicality as explained in the section below.

\subsection{Indexicality}

Indexicality refers to the property of certain elements of language (called deixis ${ }^{11}$ ) of 'pointing' to meanings like we would physically point our finger to objects (index is in fact the Latin word for finger). Deixis, more than other words, encode "the relation between objects and contexts" (Hanks, 1999: 124) as they can only be interpreted in relation to specific referents or situations. In a narrow sense, pronouns such as $I$, she, demonstrative such as this, that, and adverbs such as here, now, always exist in dual indexical forms (Kaplan 1979) or, in other words, as 'types' with semantic meaning and 'tokens' with denotational meaning. Furthermore, in broader terms, indexicality can be interpreted as "the pervasive context-dependency of natural language utterances" (Hanks 1999: 124) and it can be realised in discourse through different means. Whilst for example a regional accent can index a speaker's identity (Johnstone 2013), this can generate different orders of indexicalities (Silverstein 2003) if an ideological evaluation is associated with a social connotation (i.e. if the regional accent is associated with a specific social practice which then becomes to be regarded as an index of 'authenticity'). Further realisations of indexicality can be achieved through specific perspectivisation of a message (Renkema 2004), by means of labels, implicatures and epistemic orientations (Bucholtz and Hall 2005) which can reveal the speaker's stance towards 'objects' (e.g. a topic, a person or a relationship).

Chilton (2004) highlights how positioning and indexical anchoring can be typically realised along temporal spatial, personal, and ideological dimensions. For Chilton through deictic expressions speakers can metaphorically construct a 'deictic centre' that defines their ontological orientation to the world and their relationship with society. Indexical anchoring and positioning vis-à-vis the 'deictic centre' can ultimately be interpreted as the speaker's representation of their social identity through time, space and personal relations, i.e. their 'situatedness'. As noted earlier, the use of personal pronoun we, us and possessive adjective our can signal (dis)alignment with one particular group identity. At the same time, as they index inclusion/exclusion, personal deicitics can point to a cognitive frame that encodes a "conventional shared understandings about the struc-

11 Sometimes also referred to as deictic or indexical expressions. 
ture of society, groups and relations with other societies" (ibid to: Chilton 2004: 56). Likewise, temporal deictic expressions such as 'after the fall of the Berlin Wall' can be understood in terms of a particular historical frame involving wider ideologies beyond the temporal event itself. Similar considerations apply to spatial representations where, for example, the adverb here and the demonstrative this country can symbolically embody a frame entertained by the speaker about geo-political relations rather than simply proximity.

Building on the theoretical framework outlined above, the analysis has been primarily concerned with: a) identifying and interpreting indexical expressions that could point to different frames of transnationalism; and b) developing insights on how such conceptualisations contributed to members' identification as European. Decoding the indexical 'value' of certain utterances and linguistic items was achieved via contextual cues and operationalised at different levels of context as proposed by Wodak (2009: 67) namely: " a) the immediate, language or text internal co-text; b) the intertextual and interdiscursive relationship between utterances, texts, genres and discourses; c) the extra-linguistic social/sociological variables and institutional frames of a specific 'context of situation'; and d) the broader socio-political and historical contexts, within which the discursive practices are embedded". For example the analysis has interpreted the indexicality of now in expressions such as 'let's have a break now', 'now, this is the issue!' or 'it's difficult to get a job anywhere in Europe now' on different contextual cues and it has consequently derived different insights into the temporal positioning of the speaker.

The next section will offer some examples of how different temporal, spatial, personal and ideological deixis were deployed by members in their discourses, focusing specifically on their indexical interplay with wider transnational discourses, as made relevant to this study in the two previous sections.

\section{CONSTRUCTIONS OF EUROPEANNESS IN DISCOURSES OF TRANSNATIONALISM: USE OF TEMPORAL, SPATIAL, PERSONAL AND IDEOLOGICAL DEIXIS}

The temporal dimension was conspicuous in the focus group conducted in Cluj, Romania, where the topic of mobility introduced by the moderator gave some members the opportunity to place much emphasis on the 'freedom of movement' that Romanians can now enjoy following their country joining the EU in 2007 as exemplified by the following extract:

\section{Extract 1}

Moderator: [...] would you define yourselves as Europeans? And if you could tell me what this means to each one of you?

CL3: The right we have now, I don't know, well, I think, that we can travel more freely now, and somehow we were given more rights to do what we want, to do what we like [...] we took some distance from something that bound us, we are not bound anymore, it isn't hard to dream of something anymore, like it used to be, now you can learn more easily, as you can be with people more easily, you can interact with strangers more easily, it's more ... it's more ok than before. 
In this case the speaker constructs his Europeanness through a discursive frame revolving around Romania's accession to the EU in 2007, a key date that defines the now and before in his discourse and allows him to juxtaposes his current status of European citizen $^{12}$ ('now') with what it used to be in the past ('before'). Significantly these temporal deixis point further to the historical frame of 'mobility in the Communist era'. Under the Communist regime (1947-1989) severe restrictions applied to Romanian citizens who wanted to travel abroad. Passports were held by the police and visas were subject to government approval. Furthermore citizens who applied to emigrate had their civic and economic rights revoked and they were systematically disparaged by authorities. The relevance of being able to travel freely therefore must be interpreted in the light of such political and historical contingencies. From this perspective, the speaker sees his new status of European as an opportunity to overcome the constraints of the past communist regime that kept Romanians 'captive' in an ideological 'container' bounded by the 'iron curtain' and limiting their civic rights. Becoming a European citizen for CL3 therefore seems to index the imagination of his emancipation from slavery ('we are not bound anymore') and his validation as a free citizen. In this sense for CL3 Europe (embodied by its institutions) represents a new salient referent for renegotiating his civic affiliation away from national institutions whilst claiming his Europeanness as his membership in a community of relevance.

A different use of temporal deixis emerged from the interview with RO1 (Rome, individual interview) when the speaker constructed an argument for using English in transnational communication in Europe:

Extract 2

RO1: "Well, I think that my dream, my vision is that Europe be united politically and for this to happen [...] we need to have a language in common [...] I'm really a fan of English not because I see this as a sort of cultural imperialism, because by now English has nothing to do with England any more or with the UK [...] I don't see it as an imposition of cultural imperatives from the Brits, you know, by now English is the language of Eur... by now, you know, if aliens came to the Earth, by now, they'd probably try and talk to us in English... it's the language of old England it is the language of the US but it is the language of the EU too..."

Appealing to the universality and modernity of English, RO1 realised his argument along a temporal axis (signalled by the expressions 'by now' and 'anymore') which allowed him to represent a socio-historical evolution of English language towards the 'deterritorialisation' and the decoupling of specific cultural/identitarian connotations from communicative functions in line with a 'quasi-diglossic' scenario envisaged for European languages by most members (cf. Zappettini and Comanaru, 2014). Furthermore RO1 appealed to a cognitive schema of universality of the English language through the hyperbolic and futuristic imagery of 'aliens' expected to be able to communicate with

${ }^{12}$ Following 2007 enlargement, Romanians and Bulgarians acquired European citizenship granting rights of movement and residence in any EU member states (albeit restrictions have been applied at different times by different states). 
humans, an effective linguistic device that allowed him to contextualise issues of communication among Europeans in a global, indeed universal context of unbounded interaction.

In an individual interview conducted in Valencia (Spain), the speaker used temporal and spatial indexes to suggest the specific conditions of Spanish society and more generally of European youth:

VA1: for me belonging means not only a place you know (.) it's also belonging to a society belonging to a certain group of people that have similar values to yours (..) I mean I could say yeah I am Spanish [..] but this doesn't mean I belong to Spain (..) I don't know if I want to to to grow my roots or something like that (..) I don't know if I want to stay here you know I don't know I don't know if I want to be in South America or in the north of Europe it's not only the city or the buildings but is also the people is what you give to this society with what you contribute you know (.) I don't know where I belong (...) if you ask me now I belong to my family at the moment and no at the moment I'm not independent yet (.) I don't have a job I don't have my own house and now I don't have more options than belonging here".

Through her narrative VA1 reflexively positioned herself 'in-between' identities highlighting how her different sources of attachments had yet to fully develop into firmer feelings of belonging and groupness. VA1 represented her (European) identity as a process of 'rooting' herself in a wider social space, a process which, however she depicted as a struggle and somehow caught in-between personal choices and external constraints. VA1 constructed her difficulty to locate herself in relation to a meta-space comprising of different dimensions: a geographical dimension (specific world locations such as South/America/North Europe, or objects such buildings); an affective dimension (family, band); a social dimension of groupness (defined by the sharing of values and the moral obligation to give to society); and the historical difficult social-economic conjuncture of Spain (and more generally of Europe).

Amid this scenario the member used the spatial deictic 'here' and the temporal clause 'at the moment' to mark her precarious situatedness - a topic that VA1 discussed repeatedly in the interview and clearly echoed wider discourses of 'social precariousness ${ }^{13}$. It was thus inferable that for VA1 the contingencies of 'here' and 'now' (i.e. the lack of certainties about the future) were preventing her from emancipation and a full realization of meaningful social identities through firm ties undermining the 'ontological security' (Giddens 1991) of her identity. The gap between an ideal sense of belonging

${ }^{13}$ In the last few years there have been different movements in Spain which have campaigned in support of the right to affordable housing (VdeVivienda) and against the lack of certainty (precariedad) in employment and social welfare (Precarios en movimiento); cf also Juventud Sin Futuro (Youth without a Future) which have campaigned under the slogan 'no house, no job, no pension, no fear'. In general the deregulation of the job markets in the 1990's and 2000s has resulted in more temporary jobs being available at the expense of long-term and fixed jobs and the emergence as the 'Precariat' as a new social class (Standing, 2011). DC4E has run a number of campaigns to demand radical changes to the current job situation and VA1 has been actively involved in these activities. 
and the social and economic constraints was realized through the comparative "I don't have more options than belonging here" which presents her current choice of belongings in negative terms.

Personal deixes were also frequently deployed by members. 'The pronoun we and $u s$ and the possessive adjective our for example were inferable in several different meanings. In some cases, the indexicality of 'we' pointed to the organizational groupness, whether at the level of the local branch or the whole organization (e.g. 'our events', 'our work'). In a similar way, the 'we-citizens' (e.g. in the expressions 'our institutions') was often realised from the perspective of a local administration, the national apparatus, or the EU system. Furthermore, some members anchored the meaning of the 'we-group' to a generational belonging (e.g. 'our generation), an awareness of a socio-historical condition (e.g. 'our situation') or simply the condition of being humans (e.g. 'our emotions'). Of particular interest was the indexical use of pronouns as adjectives in representations of the interplay between Europeanness and national referents. For example, German national BE1 (Berlin individual interview) constructed her location 'outside' Germany via personal and spatial deixis as exemplified by the following extract:

\section{Extract 3}

BE1: yes I think for me I don't really identify as being German .. no not at all but this is also because of the German [...] history, they really don't have many good things to talk about .. [it] is quite strange because now, in the crisis it happens quite often that if you are German people say 'come on, but you're in Germany, and you've got money, and you can find a good job, so come on' but really, I can't be proud of it because I see the crisis from outside more than inside

BE1 used both personal and spatial deixis to distance herself from her Germanness and to invest into a transnational social location. Initially BE1 invokes the topos of history and, through the moral evaluation of the German past, she clearly dissociates herself from the negative connotations of 'being German'. The speaker's use of the pronoun they in this case suggest the negative perception of nationhood as a historical 'other'. Moreover, the 'otherization' of nationhood was made discursively relevant by the speaker through the context of the current economic crisis. In this case, whilst the member could potentially identify with a positively connoted German referent, she chooses not to do so through her spatial positioning 'outside' the national-container perspective which suggests her alignment and empathy with other fellow Europeans.

In contrast to BE1, CA1 and CA3 (both from the Cardiff focus group) used personal and spatial deixis to construct more ambivalent interplay between national and European affiliations. CA1 drew on the topos of Turkey straddling across continents/ cultures to position herself as (partly) non-European as a consequence of her Turkish identity. Likewise, CA3 invoked the topos of the UK insularity to constructing a metaphorical positioning of Britain on the edge of Europe and the ambivalent marginality of her own Europeanness.

\section{Extract 4}

CA1: I'm not a part of Europe because I'm from Turkey [rising tone] (.) actually it's both part of Europe and at the same time (..) it still isn't in the European Union and (..) yes, 
I've always been keen on studying about Europe because of its diversity there's a lot of cultures a lot of languages [...]) I think the common point is history, European history, European tradition, [...] and I think this is the point that makes us European, they share the same history

Extract 5

CA3: I like to think of Europe as...ehm ...yeah the experience of living in Europe as being transnational because I think it's very easy to move about and to exchange culture. I think living in the UK our experience is slightly different obviously being an island we are that much further away from it but I think by studying languages that, ehm that sort of distance is bridged because you spend a year abroad and obviously by speaking a foreign language you can sort of go and live in that country, and I think it becomes a lot easier [...] I think yeah certainly like the way the UK is concerned people that only speak English I think... there is definitely a distance that they don't feel European or even maybe they don't speak a foreign language but if they are sort of really interested in European cultures ....it's probably as well a political thing some people are very sort of anti-Europe I think it is based on you know the fact that we are separate and people are very keen to guard that whereas other people are much more open to integrating ourselves into Europe and I think in Europe we are also viewed differently [...] I think that the UK is in quite a unique position as being part of Europe I think.

In extract 4 the speaker realised her ambivalent European identity by simultaneously affiliating with and dissociating from the European group through the conflictual use of the pronouns $u s$ and they contextually referring to the generic 'Europeans'. CA1's extract highlights crucial tensions. In CA1's torn positioning in and out of the European space one can recognize wider discourses of inclusion and exclusion surrounding the long-debated Turkish membership of the EU and more generally of Turkish identity as Europe's historical 'other' (cf. Rumford 2011). These tensions appear to shape and constrain CA1's discourse and to be internalised by the speaker in an almost 'schizophrenic' pattern of binary belongings and shifting inclusiveness/exclusiveness. In this case, rather than compatibly integrated European and national identities were represented as intersecting whilst also functioning as antagonists.

A similarly ambivalent self-collocation in and out of Europe was achieved by CA3, a British national who characterized Europeanness primarily in relation to an understanding of transnationalism as mobility and intercultural encounters. Although she evaluated positively her engagement in transnational practices, in her discourse she appeared to index her belonging to national more than European referents. Her stance was signalled by her use of personal pronouns ('we/ourselves') and possessive adjectives ('our experience') that clearly suggest her main group affiliation as British and a general Britishcentric perspective of social interaction (cf. expressions such as 'a year abroad', 'a foreign language', and 'go and live in that country'). Furthermore through the topos of the UK insularity ${ }^{14} \mathrm{CA} 3$ emphasized the geo-cultural 'uniqueness' of Britain and constructed a marginality of its relationship with Europe, appealing to both geographical and cul-

${ }^{14}$ Cf. 'the myth of Anglo-Saxon exceptionalism' (Marcussen and Roscher, 2010). 
tural arguments. The topos of insularity was further used by the speaker as a warrant for her representation of views of the European project in the British society split between what have often been characterized as 'Eurosceptic' and 'Europhile' attitudes. Although CA3 offered a neutral representation of these two sides through the lexical choice of 'people', she consistently aligned her group membership with the British referent and its distinctiveness (her in-group positioning for example supported by the expression 'we are viewed differently'). At the same time, in her final proposition, CA3, discursively placed the UK within Europe albeit through the disclaimer on its 'uniqueness', a representation that, in relation to the extract, seems to reinforce a metaphorically peripheral positioning of Britain in relation to Europe and the speaker's own ambivalent location 'on the edge' of European identification.

\subsection{Transnational Europe: Poly-Centric Social Imaginaries}

Overall the data has suggested that members drew on (and the same time constructed) different conceptualisations of transnationalism. By and large these were oriented towards interpreting transnationalism as:

- An opportunity for the bottom-up (re)definition of civic/political community;

- The 'natural'/historical process of the demise of nationhood;

- A site of global practices of consumption, mobility, cultural exchange, and (negative/positive) economic integration.

These transnational frames seemed to operate as ideological lenses that provided members with critical and reflexive perspectives on the meaning of their activities and their social locations. Amid these frames, spatial, temporal, personal, and ideological deixis were deployed by members to position themselves and negotiate 'glocally' their (European) identities. Furthermore, different imaginaries of Europe (related to different conceptualisations of transnationalism) were recognizable which were evoked by members in relation to discursive deictic centres. As a convenient conceptualisation three notable interpretations of how the transnational European field was imagined by members are suggested as follows: nation-centric; Euro-centric; and cosmopolitan.

\subsubsection{Transnational Europe as a nation-centric field}

From a nation-centric perspective (which was invoked by a minority of members) transnationalism is the ability to interconnect across borders through different practices of mobility, cultural exchange, and so on. Intra-state mobility and the 'coming together' of different peoples/cultures are valued positively however they mainly represent 'ways of being' whilst belonging remains primarily indexed to reproduction of national identities albeit projected on a European trajectory, In other words, this vision accepts/validates the world order of states and it conceives of EU-rope as the sum of its parts that is a 'Union of states' or a 'family of peoples'. In this respect the nation-centric vision of the transnational European field corroborates Risse's (2010) findings on the 'Europe- 
anisation' of national identities, i.e. their recontextualisation at a European level. From a nation-centric perspective, the interplay between European and national affiliations in members' discourses was somewhat consistent with the 'Russian Doll' conceptualisation of hierarchically stacked identities (Herrmann et al., 2004) working in 'non zerosum' dynamics.

\subsubsection{Transnational Europe as a Euro-centric field}

The imagination of Europe from a Euro-centric perspective supported ambivalent definition of the European field as an open/closed geopolitical and social container. On the one hand, internal (physical and ideological) borders were often discursively deconstructed by members who emphasized the unboundedness of the European inside and its interconnectedness with the outside thus suggesting an open and cosmopolitan interpretation of Europe (see below). On the other hand, however, some members invoked the (cultural, social, economic, and political) boundaries of Europe and its outside to construe Europeans as a cohesive group vis-à-vis other groups (typically the Americans) and to portray EU-rope as a political entity of its own, a geo-political body that pursues 'European' rather than national interests. For most members, identification as European occurred through interpretations of transnationalism as both a way of being and a way of belonging. Through the latter interpretation transnational practices such as mobility were often seen as indexes of emancipation from nationalistic ideologies and as positive social progress. Europeanness was often interpreted in its dual nature of 'brought along' heritage and as the transformation of ethnic/national identities into civic identities 'brought about' by the EU project. The Euro-centric perspective suggested an overall interplay of national and European identities whereby the former were seen as transiting into the latter in a 'zero sum' logic.

\subsubsection{Transnational Europe as a cosmopolitan field}

Finally, through the conceptualisation of the European field enacted from a cosmopolitan perspective, members conceived of transnational dynamics as a consequence of the 'natural' interconnectedness of the (social) world. They defined their European identities reflexively and emphatically through polycentric 'locations' and often rejected the 'container theory of society'. In this case Europeanness could be seen as a 'node' or a 'gateway' capable of interconnecting individuals with(in) a wider cosmopolitan 'network' of relations, , an intermediate but not exclusive stage linking the local with the global. However, whilst in a cosmopolitan perspective Europeanness can represent a salient way of belonging, members appeared to relativise the overall salience of identities especially those derived from formal membership. Instead, for most members, the meaning of their Europeanness seemed to lay in their perception as social actors participating in a political experiment of transnational democracy that could eventually be expanded and replicated in the wider world. 


\section{CONCLUSIONS}

Trading on a transnational perspective and on the indexicality of different linguistic realisations, this paper has provided insights on how DC4E members constructed their Europeanness. It has been argued that, rather than representing an identity per se, transnationalism operated as an overarching ideological lens through which members were able to negotiate global and local dimensions often (re)constructing multiple and overlapping affiliations with Europe. Furthermore, members evoked different 'imaginaries' of Europe through indexical expressions and through the construction of their social locations in relation to different 'deictic centres'. These constructions were conveniently summarised as nation-centric, Euro-centric, and cosmopolitan conceptualisations of Europe as a transnational field. By and large, the nation-centric dimension conceives of Europe as a field of transnational practices more than of belonging. This perspective projects national identities on a European trajectory and corroborates finding on the Europeanisation of national identities in discourse. The Euro-centric conceptualization of transnationalism deconstructed Europe's internal borders and reconstructed the European field as an internally open space of belonging. However such space was also defined in relation to its outer boundaries to assimilate its inside and dissimilate its outside. From a Euro-centric perspective, therefore, the European field emerged ambivalently conceived as an open/close space and was discursively associated/dissociated with the EU project. Finally, a cosmopolitan conceptualization of the transnational European field emerged in members' discourses that, whilst rejecting nations as incongruous containers of social interaction, saw individuals networked worldwide and conceptualized the European space as immersed within a wider cosmopolitan frame. From this stance, Europe was interpreted as a site of political experimentation that could be replicated worldwide. Consequently, European identity was often seen by members as a 'node' interconnecting individuals with a cosmopolitan 'network' of practices and ties, seamlessly and simultaneously occurring at local and global levels.

The data has suggested that transnationalism can represent a powerful referent in the imagination of Europe as a space and as a community between various dimensions. Transnational narratives could drive the construction of Europeanness from bottom-up and towards postnational forms of membership alternative to institutional identity projects. The analysis has also suggested that, whilst national referents can still interplay in the imagination of Europeanness, nationhood becomes increasingly volatile as national identity referents were recontextualised, deterritorialised, represented in transition or rejected altogether by members. Of course, this study has only been able to draw a partial picture of the complex dynamics at play in the articulation of (European) identities and it would welcome further investigation on similar sites of production of Europeanness.

(C) Franco Zappettini, 2017 


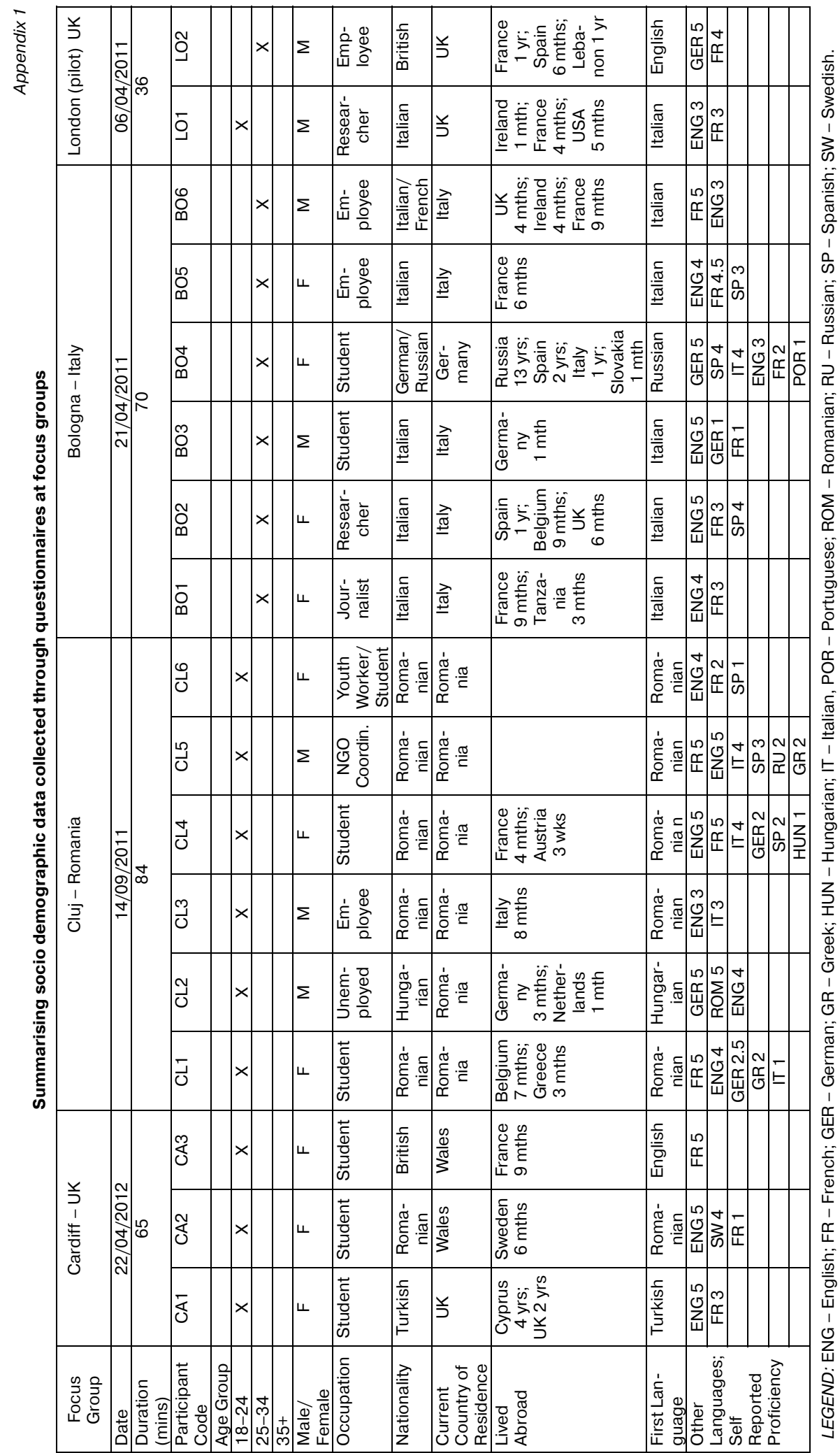




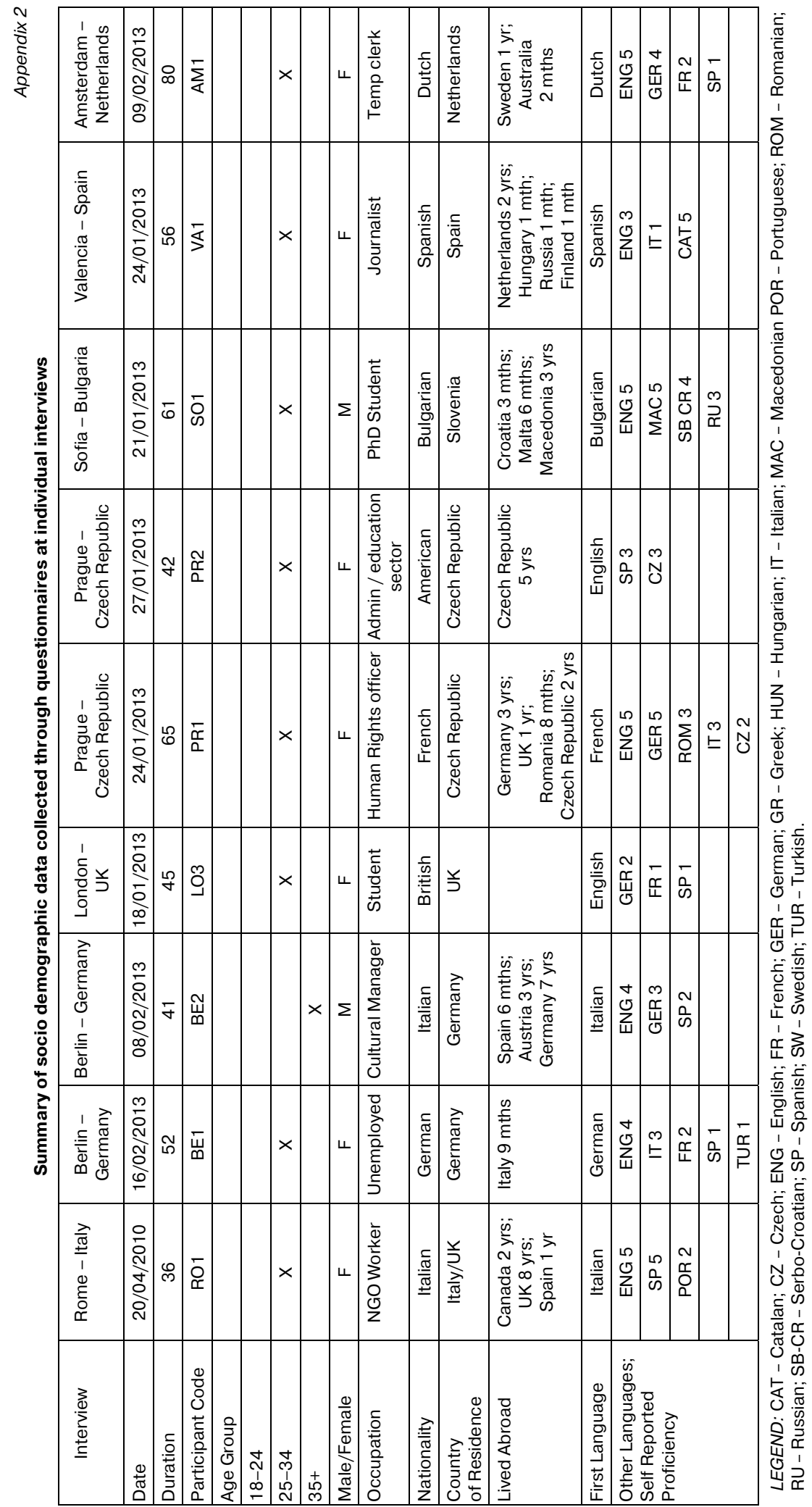




\section{REFERENCES}

Albert, M. (2001) Identities, Borders, Orders: Rethinking International Relations Theory, Minneapolis, University of Minnesota Press.

Anderson, B. (2006) Imagined communities: reflections on the origin and spread of nationalism, New York, Verso.

Appadurai, A. (1995) The production of locality. In Fardon, R. (ed.) Counterworks: Managing the Diversity of Knowledge. London; New York: Routledge.

Balibar, E. (2004) We, the People of Europe?: Reflections on Transnational Citizenship, Princeton, New Jersey, Princeton University Press.

Balibar, E. (2009) Europe as borderland. Environment and Planning D: Society and Space, 27, $190-215$.

Bauböck, R. \& Faist, T. (2010) Diaspora and Transnationalism: Concepts, Theories and Methods, Amsterdam University Press.

Beck, U. (1996) The Cosmopolitanism Manifesto. In Brown, G. W. \& Held, D. (eds.) The Cosmopolitanism Reader. Cambridge, UK; Malden, MA: Polity.

Beck, U. (2008) The cosmopolitan perspective: sociology of the second age of modernity. The British Journal of Sociology, 51, 79-105.

Beck, U., Giddens, A. \& Lash, S. (1994) Reflexive modernization: politics, tradition and aesthetics in the modern social order. Stanford, Calif., Stanford University Press.

Biebuyck, W. \& Rumford, C. (2011) Many Europes: Rethinking multiplicity. European Journal of Social Theory, 15, 3-20.

Billig, M. (1995) Banal Nationalism, London, Sage.

Blommaert, J. (2013) Citizenship, language and superdiversity: towards complexity Tilburg Papers in Cultural Studies Univesrity of Tilburg, February 2013.

Castells, M. (1997) End of Millenium. Malden, Mass., Blackwell

Cerutti, F. \& Lucarelli, S. (2008) The search for a European identity: values, policies and legitimacy of the European Union. Abingdon, UK; New York, Routledge.

Checkel, J.T. \& Katzenstein, P.J. (2009) European Identity, Cambridge University Press.

Chilton, P. (2004) Analysing political discourse: theory and practice. London; New York, Routledge.

Closa, C. (2001) Requirements of a European Public Sphere. Civil Society, Self, and the Institutionalization of Citizenship. In Eder, K. \& Giesen, B. (eds.) European Citizenship between National Legacies and Postnational Projects. Oxford, UK; New York: Oxford University Press.

Davies, B. \& Harre', R. (2001) Positioning: The Discursive Production of Selves. In Wetherell, M., Taylor, S. \& Yates, S.J. (eds.) Discourse Theory and Practice: A Reader. London: Thousand Oaks: Sage: SAGE Publications.

Debardeleben, J.H.A. (2011) Transnational Europe: promise, paradox, limits. Houndmills, Basingstoke, Hampshire, UK; New York, Palgrave Macmillan.

Delanty, G. (2013) Formations of European Modernity: A Historical and Political Sociology of Europe. Palgrave Macmillan.

Delanty, G. \& Rumford, C. (2005) Rethinking Europe: Social Theory and the Implications of Europeanization. Abingdon, Oxford, Routledge.

Della Porta, D. \& Tarrow, S. G. (2005) Transnational protest and global activism. Lanham, MD, Rowman \& Littlefield. 
Eder, K. (2009) A Theory of Collective Identity — Making Sense of the Debate on a 'European Identity' European Journal of Social Theory, 12, 427-447.

Eriksen, E.O. \& Fossum, J.E. (2001) Democracy through strong publics in the European Union? ARENA Working Paper, 01/16.

Fairclough, N., Mulderrig, J. \& WODAK, R. (1997) Critical Discourse Analysis. In Dijk, T.A.V. (ed.) Discourse studies: a multidisciplinary introduction. London; Thousand Oaks, Calif.: Sage Publications.

Fairclough, N. \& Wodak, R. (1997) 'Critical Discourse Analysis', in T. van Dijk (ed.) Introduction to Discourse Analysis.

Fligstein, N. (2008) Euroclash: The EU, European Identity, and the Future of Europe: The EU, European Identity, and the Future of Europe. Oxford, Oxford University Press.

Friedman, R. \& Thiel, M. (2012) European Identity and Culture: Narratives of Transnational Belongings. Farnham, Ashgate.

Habermas, J. (2001) The postnational constellation political essays. Cambridge, Mass.; London, MIT Press.

Habermas, J. \& Rehg, W. (1998) Between facts and norms: contributions to a discourse theory of law and democracy. Cambridge, Mass., MIT Press.

Hall, S. (1996a) The Question of Cultural Identity. In Hall, S., Held, D., Hubert, D. \& Thompson, K. (eds.) Modernity: an introduction to modern societies. Blackwell.

Hall, S. (1996b) Who needs identity? In: Hall, S. \& Du Gay, P. (eds.) Questions of cultural identity. London; Thousand Oaks, Calif.: Sage.

Hall, S. (1997) Representation: cultural representations and signifying practices. London; thousand Oaks, Calif., Sage in association with the Open University.

Haller, W.L.P. (2005) The transnational dimensions of identity formation: Adult children of immigrants in Miami. Ethnic and Racial Studies, 28, 1182-1214.

Hanks, W. F. (1999) Indexicality. Journal of Linguistic Anthropology, 9, 124-126.

Hannerz, U. (1996) Transnational Connections: Culture, People, Places. London; New York, Taylor \& Francis Group.

Hanquinet, L. \& Savage, M. (2013) The Europeanisation of Everyday Life: Cross-Border Practices and Transnational Identifications among EU and Third-Country Citizens. Eucross working papers series, 6.

Held, D. (1999) Global Transformations: Politics, Economics and Culture. Stanford University Press.

Herrmann, R.K., Risse-Kappen, T. \& Brewer, M.B. (2004) Transnational identities: becoming European in the EU. Oxford, Rowman \& Littlefield.

Hobsbawm, E. (1997) Nations and nationalism since 1780: programme, myth, reality. Cambridge, Cambridge University Press.

Jenkins, R. (2004) Social Identity, Routledge.

Johnstone, B. (2013) Speaking Pittsburghese : the story of a dialect, New York, Oxford University Press.

Jones, P. \& Krzyżanowski, M. (2008) Identity, belonging and migration: Beyond Describing 'Others'. In: Delanty, G., Wodak, R. \& Jones, P. (eds.) Identity, belonging and migration. Liverpool Liverpool University Press.

Kaiser, W.L.B. G. M. (2010) Transnational networks in regional integration: governing Europe 1945-83. New York, Palgrave Macmillan. 
Kaplan, D. (1979) On the logic of demonstratives. Journal of Philosophical Logic, 8, 81—98.

Kastoryano, R. (2003) Transnational Participation and Citizenship Immigrants in the European Union. The Challenges of Immigration and Integration in the European Union and Australia, 18 20 February 2003, University of Sydney.

Kastoryano, R.H.B. (2002) Negotiating identities, Princeton, Princeton University Press.

Kraus, P. (2006) Legitimacy, Democracy and Diversity in the European Union. International Journal of Multicultural Societies, 8, 203-224.

Krzyżanowski, M. (2010) The Discursive Construction of European Identities: A Multi-level Approach to Discourse and Identity in the Transforming European Union, Frankfurt am Main, Peter Lang.

Levitt, P. \& Schiller, N.G. (2004) Conceptualizing Simultaneity: A Transnational Social Field Perspective on Society. International Migration Review, 38, 1002-1039.

Lyotard, J.F. \& Benjamin, A.E. (1989) The Lyotard reader. Oxford, UK; Cambridge, Mass., USA, Blackwell.

Marcussen, M. \& Roscher, K. (2010) Europe and the Other and Europe as the Other. In Stråth, B. (ed.) The Social Construction of "Europe": Life-cycles of Nation-State Identities in France, Germany and Great Britain. Brussels: Peter Lang.

Mcentee-Atalianis, L. \& Zappettinl, F. (2014) Networked Identities. Critical Discourse Studies, $11,397-415$.

Mole, R.C.M. (2007) Discursive constructions of identity in European politics. Palgrave Macmillan.

Morin, J.F. \& Carta, C. (2014) EU Foreign Policy through the Lens of Discourse Analysis: Making Sense of Diversity. Aldershot; Farnham, Ashgate.

Oberhuber, F. (2007) Legitimating the European Union: The Contested Meanings of an EU Constitution. EUI Working Papers RCAS 2007 [Online], 25. Available at: http://www.eui.eu/ RSCAS/WP-Texts/07_25.pdf.

Renkema, J. (2004) Introduction to Discourse Studies. Amsterdam; Philadelphia: John Benjamins

Risse, T. (2010) A Community of Europeans?: Transnational Identities and Public Spheres. Ithaca, New York, Cornell University Press.

Robertson, R. (1992) Globalization: social theory and global culture. London Sage.

Roudometof, V. (2005) Transnationalism, Cosmopolitanism and Glocalization. Current Sociology, $53,113-135$.

Rumford, C. (2008) Cosmopolitan Spaces: Europe, Globalization, Theory. New York, Routledge.

Rumford, C. (2011) Editorial: New Perspectives on Turkey—EU Relations. Journal of Contemporary European Studies, 19, 459-462.

Salvatore, A., Schmidtke, O. \& Trenz, H.J. (2013) Struggling with the Concept of a Public Sphere. Basingstoke, Palgrave Macmillan.

Sassen, S. (1996) Losing Control?: Sovereignty in an Age of Globalization. Columbia University Press.

Shani, G. (2011) Identity-politics in the global age. In: Elliott, A. (ed.) Routledge handbook of identity studies. Abingdon, Oxon; New York, NY: Routledge.

Silverstein, M. (2003) Indexical order and the dialectics of sociolinguistic life. Language and Communication, 23, 193-229.

Splichal, S. (2006) In search of a strong European public sphere: some critical observations on conceptualizations of publicness and the (European) public sphere. Media, Culture \& Society, 28, $695-714$. 
Standing, G. (2011) The precariat the new dangerous class. London; New York, NY, Bloomsbury Academic.

Stråth, B. (2010) Europe and the Other and Europe as the Other. Frankfurt am Mein, Peter Lang.

Tajfel, H. \& Turner, J. (1979) An Integrative Theory of Intergroup Conflict. In Austin, W.G. \& Worchel, S. (eds.) The Social psychology of intergroup relations. The University of Michigan: Brooks/Cole Pub. Co.

Triandafyllidou, A., Wodak, R. \& Krzyżanowski, M. (2009) The European public sphere and the media: Europe in crisis. Basingstoke, Palgrave Macmillan.

Vertovec, S. (1999) Conceiving and researching transnationalism. Ethnic and Racial Studies, 22, $447-462$.

Vertovec, S. (2009) Transnationalism. Oxford; New York, Taylor \& Francis.

Wimmer, A. \& Schiller Glick, N. (2002) Methodological nationalism and beyond: nation-state building, migration and the social sciences. Global networks, 2, 301-34.

Wodak, R. (2004) National and Transnational identities: European and Other Identities Constructed in Interviews with EU Officials. In Herrmann, R.K., Risse-Kappen, T. \& Brewer, M.B. (eds.) Transnational identities: becoming European in the EU. Rowman \& Littlefield.

Wodak, R. (2009) The discourse-historical approach In Wodak, R. \& Meyer, M. (eds.) Methods of Critical Discourse Analysis (2nd Edition). London: Sage.

Wodak, R. (2012) Reinventing nationalism: recontextualising traditional themes in glocal politics First International Conference on the Discourse of Identity. Santiago de Compostela.

Wodak, R., De Cillia, R., Reisigl, M. \& Liebhart, K. (2009) The discursive construction of national identity. Edinburgh, Edinburgh University Press.

Wodak, R. \& Koller, V. (2008) Handbook of Communication in the Public Sphere. Berlin; New York, Mouton De Gruyter.

Wodak, R. \& Weiss, G. (2005) Analyzing European Union discourses: Theories and applications In Wodak, R. \& Chilton, P. (eds.) A New Agenda in (Critical) Discourse Analysis: Theory, Methodology and Interdisciplinarity. Amsterdam: J. Benjamins.

Zappettini, F. \& Comanaru, R. (2014) "Bottom-Up Perspectives on Multilingual Ideologies In The EU: The Case Of A Transnational NGO” Journal of Contemporary European Research, 10.

\section{Article history:}

Received: 12 December 2016

Revised: 01 February 2017

Accepted: 14 February 2017

\section{For citation:}

Zappettini, F. (2017). Transnationalism as an Index to Construct European Identities: An Analysis of 'Transeuropean' Discourses. Russian Journal of Linguistics, 21 (2), 260-281.

\section{Bio Note:}

Franco Zappettini, $\mathrm{PhD}$ in Applied Linguistics, Professor at University of Genoa. Research Interests: Critical Discourse Analysis, Cultural Identity, Multilingualism, Discourse, Language, Discourse Studies, Interpretation. Contact information: e-mail: franco.zappettini@gmail.com 


\title{
РОЛЬ ТРАНСНАЦИОНАЛИЗМА \\ В КОНСТРУИРОВАНИИ ЕВРОПЕЙСКИХ ИДЕНТИЧНОСТЕЙ: АНАЛИЗ «ТРАНС-ЕВРОПЕЙСКИХ» ДИСКУРСОВ
}

\author{
Франко Заппеттини \\ Университет Генуи \\ 5 Via Balbi, 16126 Генуя, Италия
}

\begin{abstract}
Транснационализм - это многогранное явление, оказывающее влияние на общество и ведущее к смене парадигмы национальной принадлежности. Транснационализация неоднозначно оценивается в контексте Европейского Союза, где обсуждаются, оспариваются и узакониваются новые общности и зарождающиеся пост-национальные идентичности. Данная статья - это попытка осмыслить восходящие процессы дискурсивного конструирования идентичностей в публичной сфере посредством анализа дискурсов членов неправительственной организации «активных» граждан. В работе используется критический дискурс-анализ (КДА), позволяющий показать, каким образом дискурсивные стратегии и языковые приемы, используемые говорящими и непосредственно связанные с указанием на транснациональные фреймы, конструируют модели принадлежности к современной Европе. В статье предлагается классификация параметров транснационализма, реализующихся в дискурсах и подразделяющихся на национально-центрический, евроцентрический и космополитический.
\end{abstract}

Ключевые слова: транснационализация, дискурсивные стратегии, пост-национальные идентичности, языковые приемы, публична сфера

\section{История статьи:}

Дата поступления в редакцию: 12 декабря 2016

Дата принятия к печати: 14 февраля 2017

Для цитирования:

Zappettini F. Transnationalism as an Index to Construct European Identities: an Analysis of 'Transeuropean' Discourses // Вестник Российского университета дружбы народов. Серия: Лингвистика. 2017. Т. 21. № 2. С. $260-281$.

\section{Сведения об авторе:}

Франко Заппеттини, доктор, профессор Университета Генуи (Италия). Сфера научных интересов: критический дискурс-анализ, культурная идентичность, мультилингвизм, теория дискурса, переводоведение. Контактная информация: franco.zappettini@gmail.com 